\title{
On the Epistemological Similarities of Market Liberalism and Standpoint Theory
}

\author{
Raimund Pils ${ }^{1 \star}$ (D) and Philipp Schoenegger ${ }^{2}$ (D) \\ ${ }^{1}$ Department of Philosophy (KGW), University of Salzburg, Austria and ${ }^{2}$ University of St Andrews, UK \\ *Corresponding author. Email: raimund.pils@sbg.ac.at
}

(Received 26 September 2020; revised 23 January 2021; accepted 8 March 2021)

\begin{abstract}
In this paper, we draw attention to the epistemological assumptions of market liberalism and standpoint theory and argue that they have more in common than previously thought. We show that both traditions draw on a similar epistemological bedrock, specifically relating to the fragmentation of knowledge in society and the fact that some of this knowledge cannot easily be shared between agents. We go on to investigate how market liberals and standpoint theorists argue with recourse to these similar foundations, and sometimes diverge, primarily because of normative pre-commitments. One conclusion we draw from this is that these similarities suggest that market liberals ought to, by their own epistemological lights, be more attentive towards various problems raised by feminist standpoint theorists, and feminist standpoint theorists ought to be more open to various claims made by market liberals.
\end{abstract}

Keywords: Liberalism; social epistemology; feminism; Hayek; Standpoint theory; market epistemology

\section{Introduction}

In this paper, we investigate the similarities between the epistemological assumptions of market liberalism and standpoint theory. The focus will be the claims that some knowledge is dispersed in society such that only some agents have access to it, and that this knowledge is hard or impossible to share with others. This is an insight that is shared by both market liberals and standpoint theorists. In a nutshell, market liberals hold that individuals have knowledge related to their place and time that is inherently hard to share and that enables a decentralized market to efficiently allocate resource and supports productive innovations. The context of this discourse is largely one of knowledge as it relates to economic endeavors such as regulatory mechanisms, price-setting, or technological innovation. Standpoint theorists, on the other hand, argue that some personal characteristics like gender can have a substantive impact on knowledge creation such that some knowledge is in the hands of only those who share a certain experience in life, and that this knowledge cannot simply be shared with others. Much of the current literature focuses on aspects of the social world, specifically factettes of oppression and experience. In an attempt to investigate the similarities between these two positions, the specific features of interest in this paper are (i) the fragmentation of knowledge in society and (ii) the inability of individuals to share this knowledge directly. In our 
paper, we closely examine the similarities between these two positions by recourse to the two underlying epistemological features and argue that, despite their political oppositions, both sides ought to adapt or at least be more attentive to some of the claims of the respective other. These similarities between market liberalism and standpoint epistemology are not yet recognized, even though the general idea of combining the price mechanism with something like a perspectival analysis was recently, for example, done by Muldoon (2016) and Gaus (2019) in the context of political theory. ${ }^{1}$

We structure the paper as follows. In 1.1 and 1.2, we introduce market liberalism and standpoint theory. Specifically, we motivate this paper by drawing on a Hayekian view of dispersed knowledge as a foundation for functioning markets and by drawing on a feminist view of standpoint theory inspired by, for example, Harding and Collins, that discusses the contexts of gender and race. We then go on to briefly discuss the frequent political opposition between these two positions. In 2, we make explicit how the epistemological commitments of both market liberals and standpoint theorists relate to each other. Particularly, we highlight where similarities survive contact with the other and where substantive differences emerge. In 3, we draw together these findings and suggest a productive path forward for both market liberals and standpoint theorists by recourse to a number of examples in which we put the above results to work.

\subsection{Market Liberalism}

In this section, we introduce Market Liberalism and its epistemological assumptions. We understand market liberalism to be a liberal political theory proposing that society should be structured according to a market-oriented system and ought to be combined with a limited and neutral state. The central claim of market liberalism is that a market economy fosters the ends of a liberal society best. ${ }^{2}$

In this paper, we put the focus exclusively on one central motivating epistemic argument for market liberalism: the Knowledge Argument by F.A. Hayek. ${ }^{3}$ Hayek's knowledge argument, which went on to directly influence a large number of market liberal theorists, was initially formulated as an argument against market socialism as conceived of in the socialist calculation debate of the 1930s (cf. Von Mises 1920; O'Neill 2006;

\footnotetext{
${ }^{1}$ In this sense, our project is not wholly novel. This pertains to attempts at outlining accounts of justice in morally and otherwise heterogeneous societies. For example, Gaus (2019) puts forward a novel theory that draws directly on irreconcilably diverse perspectives within society that give rise to deep disagreements (Gaus 2019). Engaged in a similar project, Muldoon (2016) specifically addresses the challenge of judgement aggregation procedures in cases of vastly diverging perspectives. He argues that a price mechanism "allows agents with different perspectives to engage with each other in a way that doesn't privilege any given perspective" (Muldoon 2016: 84). Furthermore, see D'Agostino (1996) on the problem of public justification in relation to perspectivally diverse agents. Yet, our approach applies to the context of feminist standpoint theory specifically. Here, the similarities to market liberal epistemology and its implications are not yet recognized, even though much of recent feminist scholarship on the topics of race and gender draws on standpoint theoretic methodology.

${ }^{2}$ Note that this is shared by neoliberals, libertarians, and laissez-faire capitalists more generally, though there are some theoretical differences (e.g. on the question of the justified role and size of the state). However, for the purposes of this paper, the reader can understand the use of our concept of MARKET LIBERALISM as roughly equating to any of the aforementioned political and economic theories without any loss of understanding.

${ }^{3}$ Importantly, Hayek's Knowledge Argument is not the only motivating argument for market liberalism. However, it has been exceptionally central in both the academic discussions (as evidenced in the main text) as well as the political implementations. For example, Margaret Thatcher is reported to have held up Hayek's Constitution of Liberty at a Conservative Party's policy meeting while proclaiming that "this is what we believe" (Ranelagh 1991). Similarly, both Ronald Reagan and George Bush cited Hayek approvingly in support of their visions of the world (Evans and Novak 1981: 229).
} 
Cerovac 2018; Thicke 2018). ${ }^{4}$ The fundamental point of Hayek's contribution is the insight that knowledge is inherently fragmented in society ${ }^{5}$ and sometimes cannot be shared between actors. On Hayek's view, a well-functioning liberal polity must enable the market mechanism to function freely and uninhibitedly by top-down planning. This is primarily because the "knowledge of the circumstances of which we must make use never exists in concentrated or integrated form, but solely as the dispersed bits of incomplete ... knowledge which all separate individuals possess" (Hayek 1945: 519) and whose individual interactions with each other lead to a spontaneous order via the price mechanism (Petsoulas 2013; Colin-Jaeger Forthcoming). In Hayek's words, the fundamental economic problem of society is a "problem of the utilization of knowledge not given to anyone in its totality" (Hayek 1945: 520). The only system that can achieve to properly draw on this wealth (cf. Radnitzky 1992: 224) of dispersed individual knowledge, the market liberal holds, is a competitive free-market system that utilizes the price system for aggregation of this knowledge (cf. also Epstein 2005: 205; Friedman 2013: 277; Colin-Jaeger and Delcey 2020).

This central epistemological insight is translated into two practical claims. First, Hayek demonstrates that central planning is exceedingly inefficient because knowledge is dispersed in society (Khalil 2002). In the picture presented by Hayek, as Friedman (2013: 278) puts it, "central planners would face insuperable epistemic barriers" in their attempt to plan the economic and regulatory structures of society, primarily because the knowledge held by individuals throughout society cannot simply be shared and transmitted to a centralized decision-maker that would then have to act on this aggregate. Such a challenge, so the claim, would be better solved by a bottom-up system in which individuals act on their own and, by doing so, further the public good indirectly.

Second, Hayek points out that the competitive process leads to discovery and utilization of knowledge that would otherwise not be achievable (Bento 2014). Specifically, Hayek argues that it is the competitive market process that enables individuals with their specific knowledge of time and place to know where to search for innovation opportunities and how to exploit them. He continues that this ability of the entrepreneur to correctly identify conditions ripe for innovation is best able to function when "the market tells them what kinds of goods and services are demanded, and how urgently" (Hayek 2002: 13) in a non-distorted manner. As such, the fundamental problem of "find[ing] out what kinds of material and human productive forces are present" (Hayek 2002: 19) is again best solved via a decentralized market process. $^{6}$

\footnotetext{
${ }^{4}$ While the Hayekian argument is one advanced against epistocratic government and central planning, its negative case can also be expanded to "egalitarian deliberative demorac[ies] characterized by large state[s] and complex decision-making procedures" (Cerovac 2018: 81). Further, the Knowledge Argument is also understood to be a critique of positivistic neoclassical economic theory and their equilibrium models in particular (cf. Kiesling 2015: 46-9; Whyte 2019: 11-12). For contemporary empirical tests of Hayek's thesis, compare e.g. Schultz and Libman (2015) as well as Huang et al. (2017).

${ }^{5}$ This knowledge, as O'Driscoll Jr. puts it, is "localized across the population of economic agents" (O’Driscoll Jr 2016: 337).

${ }^{6}$ For Potts, the problem of innovation is practically identical to the problem of dispersed knowledge. In other words, the problem of innovation, being a knowledge problem, is in essence a problem of "finding combinations of different pieces of knowledge that reveal valuable opportunities on which entrepreneurs might act" (Potts 2016: 6). Some institutional arrangements are better at drawing on this dispersed knowledge, e.g. bottom-up ventures, while others, more centralized, fail to effectively aggregate that knowledge and innovate accordingly (Pohl 2017). As Potts points out, this then extends the application of Hayek's knowledge problem to contexts of novel information to already present economic systems, as well as to the "problem of identifying and coordinating distributed knowledge for entrepreneurial discovery of
} 
The underlying claim of the knowledge argument that motivates both Hayek's opposition to central planning and his endorsement of the market process as a discovery tool pertains to the location of knowledge. The main claim is that some knowledge is necessarily dispersed. Hayek's original understanding of this knowledge in question was to describe it as one of the "particular circumstances of time and place" (Hayek 1945: 521). For him, it was "with respect to this that practically every individual has some advantage over all others in that [they] possess ... unique information" (Hayek 1945: 521) that others do not and indeed sometimes cannot possess. Consider the original example below.

Assume that somewhere in the world a new opportunity for the use of some raw material, say tin, has arisen, or that one of the sources of supply of tin has been eliminated. ... All that the users of tin need to know is that some of the tin they used to consume is now profitably employed elsewhere, and that in consequence they must economize tin ... The whole acts as one market, not because any of its members survey the whole field, but because their limited individual fields of vision sufficiently overlap so that through many intermediaries the relevant information is communicated to all. (Hayek 1945: 526)

On Hayek's view, every person can (and often does) possess some knowledge specific to their own situation. In the example above, it could be that a craftsman from Inverness who had received their supply of tin from a mine near Loch Eriboll heard of the collapse of said mine from a trusted friend. Knowing that this means that their supply of tin will soon dry up, they are forced to switch to producing their craft from another metal or be willing to pay a higher price as those supplying the tin will signal the reduction in supply by raising the price. Being confronted with this decision and knowing that the tin mine near Loch Eriboll will not open in the foreseeable future, they decide to produce different handicraft to remain profitable. ${ }^{7}$

For the market liberal, there is one crucial lesson to draw from this based on the first of Hayek's insights laid out above: It would be epistemically impossible for a central planner to order this craftsman from Inverness as well as all other economic actors whose choices are impacted by that mine collapse to stop using tin for their handicraft and to respond properly to the change in the economic landscape based on the news of the mine collapse. This is because a single central planner or even a planning committee cannot possess all the relevant knowledge that all individuals engaged in this and proximate industries have. That knowledge includes sharable but also difficult to share knowledge that some individuals possess by virtue of their position in time and space, and as such, in society. No single person can accumulate all that knowledge and issue all the relevant orders in response to that. This points to the coordination problems that Hayek took to be inherent in socialism and is one of the most fundamental motivating principles of market liberalism.

opportunities" (Potts 2016: 11) for future applications. Empirically, productivity growth (at industry level) has been found to correlate positively with competition overall, with average innovation (within industries) and competition found to be standing in an inverted U-relationship, i.e. positively when competition is comparatively low and negatively when it is comparatively high. (Aghion et al. 2005; cf. also Dutz and Hayri 1999; Tingvall and Poldahl 2006; Bento 2014).

${ }^{7}$ As Friedman (2013) points out, for Hayek this fact alone does not yet suffice for whether this craftsman's action is indeed profitable, as this does depend on how "well his interpretation of this local information captures realities in the wider economy, since those realities will determine the future price of the goods he will try to sell" (Friedman 2013: 286). However, this point is orthogonal to the knowledge question discussed in this paper. 
Even though the argument relating to central planning has received much attention in the literature (cf. Butos 2003; O'Neill 2006; Caldwell 2008; Whyte 2019), it is not the main concern of this paper. The relevant take-away for the purposes of this paper is the epistemological basis for this claim, namely that this craftsman has some specific knowledge of place and time which other actors in the same economy do not possess (and indeed cannot possess due to them not sharing location, time, personal experience, and so on). This craftsman from Northern Scotland (and many like them), so the market liberal claims, possesses a certain level of epistemic advantage over other actors which they then communicate through economic actions and the setting of appropriate prices as a signal in the economic order. ${ }^{8}$ This knowledge, as Kiesling (2015) points out, is "dispersed, private, local, often tacit, frequently inarticulate, sometimes ephemeral, and usually contextual" (Kiesling 2015: 62).

A second, similarly central claim is that sometimes, knowledge is not only dispersed in society, but it is also the fact that significant amounts of relevant knowledge simply cannot be shared between agents. The claim here is that knowledge sometimes cannot be shared specifically due to the nature of the knowledge in question, which makes us face an insurmountable "impossibility of conveying" (Oğuz 2010: 146). As Oğuz lays out, for Hayek and the market liberals following in this tradition, there is knowledge such that "personal dimension[s] make [it] categorically different" (Oğuz 2010: 147) from the type of knowledge that can easily be plugged into a cost-benefit analysis (e.g. one's preferred wage rate or one's willingness to pay for a product). What makes this knowledge so categorically different based on its personal dimensions is not made fully clear by Hayek (except for the fact that it has something to do with the personal characteristics of it, and that it is dispositional, such that agents are following rules without knowing them).

On some interpretations, one can understand this knowledge as tacit knowledge, with Hayek frequently drawing on Polanyi (and Ryle) who held that "we can know more than we can tell" (Polanyi 1966: 4). For example, Hayek describes knowledge as sometimes being such that we cannot "ever explicitly state or exhaustively describe" (Hayek 1952: 152) it in a way such that "we always know ... more than we can deliberately state" (Hayek 1967: 60-1). This "hardly even articulable" (Hayek 1988: 89) knowledge is essential to the market process and the signaling role of prices, especially when it comes to innovation. Returning to the topic of innovation to provide an example, Hayek lays out that "an entrepreneur's hunch that a new product might be successful ... would prove impossible to [be made] public quite apart from considerations of motivation" to do so (Hayek 1988: 89). This knowledge has a personal dimension that makes it both impossible to share and integral to the market process. In other words, "some part of knowledge remains tacit all the time" (Oğuz 2010: 161). ${ }^{9}$ As such, significant amounts of knowledge that the market liberal understands as fundamental to the functioning of a capitalist economy is tacit and personal in such a way that it cannot be shared between individuals.

In sum, market liberals acknowledge and indeed make central to their theory the epistemological claim that our knowledge-generating processes are necessarily imperfect and often wholly personal, and that only the market is able to properly take into account and aggregate all the localized, sometimes tacit, knowledge within a society efficiently (cf. Whyte 2019: 11). For market liberals, individual differences in epistemic access to certain states of affairs are a necessary stepping stone towards explaining

\footnotetext{
${ }^{8}$ For how Hayek's view of dispersed knowledge relates to the notion of bounded rationality, compare Fiori (2009: especially 273-5).

${ }^{9}$ This is a common interpretation of Hayek. See, for instance, Vaughn (1994: 122) and Fleetwood (1995: 97).
} 
how and why market economies with a limited state, largely free-reining markets, and an unconstrained price mechanism outperform both epistocracies and egalitarian deliberative democracies that may lack some of these features, as well as to why such a system is important for fostering innovation. Further, it is the combination of both the dispersion of knowledge and the inability to share other types of knowledge that makes this system work. ${ }^{10}$ To summarize, it is integral to the market liberal's view that individuals in society have different epistemological advantages over each other. Those advantages, expressed through the price mechanism, then lead to an efficient allocation of the resources available in a competitive free-market system that is well-suited for innovation and discovery. This argument relies on the fundamental claims (i) that knowledge is dispersed throughout society, (ii) that the position in society (time/place etc.) influences what knowledge one possesses, (iii) that significant amounts of knowledge (e.g. tacit knowledge) cannot be articulated or shared, and (iv) that the market process is best suited at dealing with (i), (ii), and (iii). In the remainder of this paper, we will focus on (i) - (iii).

\subsection{Standpoint theory}

In this section, we introduce standpoint theory. Standpoint theories are best categorized as feminist social epistemologies. As such, they are especially concerned with the analysis of the belief-forming processes of individuals and groups in society as well as the question of how these processes relate to the formation of knowledge. ${ }^{11}$ Especially early feminist epistemology (cf. Code 1981; Harding 1982) aimed at understanding the impact of gender on knowledge acquisition. Later advocates of standpoint theory (cf. Collins 1990; Naples 2009) extended this field of research from gender to a variety of other social identities while retaining the focus on underprivileged social groups, thus moving towards an intersectional direction (Naples and Gurr 2013). ${ }^{12,13}$ The epistemological core thesis of standpoint theorists is that because of one's perspective and experience in life, various people have unique knowledge that cannot simply be shared with others via standard means.

Specifically, standpoint theory investigates the relation between social identities and knowledge based on the concept of PERSPECTIVAl Differences. Perspectival differences concern the essentially different perspectives individuals or groups can have on a certain domain of inquiry. First and foremost, this conception of perspectival differences has to be distinguished from the fairly trivial assessment that different subjects in a society have different experiences, and thus acquire different items of knowledge. Much more fundamentally, standpoint theory claims that knowledge is shaped by one's own perspective as part of a group to such an extent that it is in principle impossible for a member of a different group to acquire such knowledge. In other words, some experiences are such that someone else who cannot access them (because they are

\footnotetext{
${ }^{10}$ For a survey of the experimental evidence on information in financial asset prices, compare Page and Siemroth (2020) to see this assumption tested empirically.

${ }^{11}$ Commonly used formulations of standpoint theory such as these suggest a reliabilist approach, as developed by Goldman (1979). This is the prototypical method of justification used in social epistemology, adopted in standpoint theory, for instance, by Michaelian (2008). Our paper, however, is independent of any specific epistemological method of justification, such as reliabilism or evidentialism.

${ }^{12}$ For example, Naples' (2009) framework incorporates race, gender, class, sexuality, and culture more generally in analysing the epistemic grounds of distinct intersectional positions in society. For a recent account of how an intersectional analysis can produce novel insights, compare Al-Ali (2020).

${ }^{13}$ For an account that argues that feminist empiricism and standpoint theory ought to merge, see Intemann (2010).
} 
specific to the experiences of a certain sex, gender, ethnicity, etc. ${ }^{14}$ ) cannot gain certain knowledge related to that experience, even if those holding the knowledge tried to share it directly. As such, standpoint theory implies a necessary fragmentation of knowledge in society, a stance that has become known as the Group Fragmentation Thesis.

Group Fragmentation Thesis: Perspectival differences that rest on unique characteristics of group identities generate significant amounts of knowledge for a group that can in principle not be shared with other groups.

The Group Fragmentation Thesis can be subdivided into two sub-theses. First, the claim that the uniqueness of the belief-forming processes of members of a group $G$ generates various justified true beliefs for $G$ that cannot be generated by members outside of $G$. Second, the unique nature of the group-specific belief-forming processes prevents such knowledge to be shared to members outside of $G$. Note that the Group Fragmentation Thesis does not imply that the epistemic out-group cannot form the beliefs of the epistemic in-group (even though this position might be advanced independently as well). Instead, it suggests that the justificatory processes of the in-group are not accessible for the out-group, and since justification is a necessary condition for knowledge, the epistemic out-group cannot access said knowledge.

As Kukla (2006) showed extensively, this breaks with the widely shared traditional view of epistemology that epistemic warrant needs objective accessibility. While some standpoint theorists argue that, thus, standpoint theory is necessarily epistemically relativist (cf. Ashton 2020), Kukla (2006) maintains that this is still compatible with an objectivist epistemology, while Haraway (1988) suggests that one should move beyond the objectivism-relativism dichotomy altogether (cf. also Harding 1992; Hamati-Ataya 2014: 168-70).

One of the most widely discussed disagreements in standpoint theory relevant for the purposes of our paper is the scope of epistemic significance. Early advocates stress especially the significance of one's position in society for understanding social relations. However, the application of standpoint theory was later extended to a wide variety of fields of knowledge. One example is the effect of social location on science, be it on social sciences or natural sciences (cf. Wylie 2003; Crasnow 2013). As Toole (2019) lays out in detail, standpoint theory originates in the ideas of Karl Marx and Georg Lukács in the context of the proletarian standpoint. It is argued that the exploited working class has significant epistemic privilege over the rich and the factory owners because of their unique position in society - a view foreshadowing contemporary standpoint theory. Smith (1974) adjusts this proletarian perspective by replacing the class analysis with a gender analysis. This gender-focused version of the Marxist framework then became the core of mainstream standpoint theories, for example those advocated for by Hartsock (1983), Jaggar (1983), or Harding (1991).

Hartsock (1983) emphasizes especially the experiential differences and epistemic consequences of a socially underprivileged oppressed group compared with an oppressor group. Following Hartsock (1983), by applying the concept of perspectival differences to the analysis of dominant and oppressed groups, standpoint theorists, such as Harding (1991) and Collins (1990), developed the thesis of Bifurcated Consciousness. Its main claim is that oppressed groups have privileged access to knowledge. The reason for this special epistemic advantage is that only individuals of the oppressed groups have the ability to see both perspectives by experiencing their

\footnotetext{
${ }^{14}$ This may include the experience of being Black in America, of undergoing childbirth, or of being a woman (and all their possible intersections).
} 
marginalized situation uniquely. ${ }^{15}$ The dominant groups, on the other hand, as Mills (2007) and Tuana $(2004,2006)$ argue, even have an additional incentive for being ignorant about their unearned privilege. Rolin $(2006,2009)$ calls this the Thesis of Epistemic Advantage. As Harding puts it, standpoint theories "map how a social and political disadvantage can be turned into an epistemic, scientific and political advantage" (Harding 2004: 7-8).

Note that the early Marxist roots of standpoint theory were already based around an analysis of the epistemic significance and social location for market interactions which we will pick up again in this paper at a later point. Notice further that the classical Marxist perspective interpreted as a proletarian standpoint theory makes it plausible that the standpoint also plays a significant role not only for the proletariat, but also for their respective labor occupations. From this more fine-grained perspective, any proletarian sub-group, such as weavers or construction workers, for example, will have unique experiences that shape their life-world and give them privileged access to specific kinds of knowledge, implying the Group Fragmentation Thesis.

In summary, the presented picture of feminist standpoint theory is one in which both individualistic and group characteristics have a direct influence on knowledge of such kind that cannot always be shared between individuals.

\subsection{On the perceived opposition of feminist theory and Market Liberalism}

In this section, we want to clarify the current relationship between (standpoint theoretic) feminist theory and capitalist theory with respect to what is often perceived to be a political opposition. We understand that due to the heterogeneity in both traditions of thought, any exhaustive overarching account of their interrelations will be necessarily incomplete. Yet in essence, we draw on the perhaps obvious point that feminist theory and capitalist theory often stand in a contrapositive relation. In the later sections, we argue for a degree of bridge-building, given the common epistemological core.

Historically speaking, standpoint theory draws heavily on Marxist theory (cf. Hekman 1997: 341-2). ${ }^{16}$ It goes without saying that prima facie, any theory rooted in Marxism is opposed to market liberalism as outlined above. ${ }^{17,18}$ Various recent feminist epistemologists, however, criticize the Marxist elements of classical standpoint theory by contending that the Marxist perspective, as Hekman (1997: 341) writes, "has been discredited in both theory and practice," and as such ought not to be given particularly high credence. Thus, scholars such as Hekman (1997) strip standpoint theory from its materialist essentials and take a postmodern and poststructuralist perspective instead. What all of these perspectives (i.e. Marxism, postmodernism, and poststructuralism) have in common, however, is their vehement criticism of capitalism which thus constitutes, at least in its origins, a fundamental tenet of all main strands of feminist standpoint theory.

\footnotetext{
15“Starting off research from women's lives will generate less partial and distorted accounts not only of women's lives but also of men's lives and of the whole social order" (Harding 1993: 56).

${ }^{16}$ See also, for instance, Rose (1983), Young (1980), O’Brien (1981), or Jaggar (1983).

${ }^{17}$ Fraser (2012) argues that, early on, feminism posed a substantive challenge to capitalism, though it then merged into neoliberal capitalism. Today, Fraser claims, feminism is well positioned again to "reinvent feminist radicalism" (Fraser 2012: 4) in opposition to current capitalism. See also Bargu and Bottici (2017: 7) and Luxton (2014: 137).

${ }^{18}$ Many of those criticizing capitalism from a socialist feminist perspective draw on Karl Polanyi (1944). Polanyi, a contemporary of Hayek's, had clashed multiple times with both Mises and Hayek and is generally viewed as the socialist counterpart to the Austrian School of Economics. For how Hayek's and Polanyi's account of tacit knowledge interacts with this, compare Oğuz (2010).
} 
This opposition is not merely historical. ${ }^{19}$ The underlying claim, shared by the majority of theorists working in this field, is that the oppression of women in patriarchy stands in some important relation to capitalism. ${ }^{20}$ It should be pointed out, however, that there is also a liberal strand of feminism, ${ }^{21}$ and thus such an opposition to capitalism is not categorical. Still, when it comes to standpoint theory, the factual opposition is apparent.

On the market liberal side, Epstein (1995), for example, has argued that employment discrimination laws ought to be rejected on the grounds of them limiting the freedom of choice, introducing destructive government constraint, and thus mandating inefficient employment patterns. Similarly, Hayek is often quoted in his opposition to social justice, e.g. by seeing in it a threat that might lead to the "destruction of the indispensable environment in which the [...] value of personal freedom [can flourish]" (Hayek 1976: 67), though whether he exactly meant what is currently understood under the term is less clear (see Lister 2013). As far as feminism is intertwined with anti-capitalist sentiments, this necessarily creates an opposition to market liberalism. However, the feminist goals per se are frequently shared by market liberals. For example, already in the 1920s Von Mises (1951) argued that giving women complete economic freedom would be an important step towards equal treatment under the law and equality more generally. He states that "[a]ll mankind would suffer if woman should fail to develop her ego and be unable to unite with man as equal, freeborn companions and comrades" (Mises 1951: 105). Also today, market liberals frequently point out and oppose various sexist limits the state puts on women's freedom (cf. Kirp et al. 1986: 204).

Given the evidence presented above, we conclude that feminist theory is frequently opposed to capitalist thinking, especially in the realm of standpoint theory. On the side of market liberalism, at least some, like Hayek, were adamantly opposed to some of the social justice goals of feminist theory (cf. Hayek 1976: 33, 67-8, 80, 97), others share feminist goals and are merely opposed to frequent anti-capitalist sentiments of feminist theorist, or anti-capitalist means in pursuit of feminist goals.

\section{On similarities, differences, and compatibilities}

In this section, we investigate the similarities and differences between standpoint epistemology and market liberal epistemology. As shown in section 1.1, the three core structural features of market liberal epistemology are (i) that knowledge is dispersed, (ii) that the position in society (time/place etc.) influences what knowledge one possesses, and (iii) that significant amounts of that knowledge cannot be articulated or shared. As shown in section 1.2, feminist standpoint theory shares all three of these features. Like market liberals, standpoint theorists too claim (i) that knowledge is dispersed. The analysis of perspectival differences explains this by (ii) the position in society, especially pertaining to features such as sex, gender, and ethnicity. The core feature of the

\footnotetext{
${ }^{19}$ We recognize the inherent difficulties in disentangling historical and theoretical oppositions, as both influence each other substantially. For example, Luxton (2014) distinguishes (historical) political activism and theoretical advances, though, as Ferguson (2014) points out, one ought to "hesitate to pry these apart (Ferguson 2014: 161), all the while the counterbalancing tendency to conflate them also threatens theoretical clarity.

${ }^{20}$ See, for instance, Eisenstein (1979), Mojab (2015), and Bargu and Bottici (2017), on gender domination, Aulenbacher et al. (2018) and Lyberaki (2011) on unpaid or minimally paid care work of women, Oksala (2017) on sexual regulation, Lara (2017) on ecological responsibility, Walby (1989: 214-15), Fuchs (2018), Harvey (2005), and Moore (2015) on the intersections of gender with race and class more generally, and Walby (2013) on the historical interconnections of these.

${ }^{21}$ For an overview, see Baehr (2021).
} 
Group Fragmentation Thesis is identical to (iii), while adding a group dimension as an explanation to why this is the case. Concerning (iii), both argue for the existence of a unique type of knowledge - knowledge that is not sharable across society. Since this type of knowledge is foreign to traditional epistemology, and its advocacy is indeed quite revolutionary by disconnecting warrant from objective shareability (cf. Kukla 2006), it is by itself already a surprising finding that both, standpoint theory and market liberal epistemology, share this basic assumption. However, even though the epistemological core is almost identical, there are also areas of apparent disagreement on various details of this proposal. Yet on a more careful investigation, many of those disagreements turn out to be reconcilable. In what follows, we closely compare the epistemological commitments of market liberals and standpoint theorists and ultimately conclude that there exist a surprising number of basic commonalities and compatibilities.

At face value, it might seem that market liberal epistemologies would be dissimilar to traditional feminist standpoint theories in that the former endorse an individualistic framework (Hayek 1945: 519) whereas the latter endorse a group-relative framework, expressed through the Group Fragmentation Thesis. We now want to suggest a synthesis by addressing two points. On the one hand, standpoint theorists can and should allow for an individualist dimension. On the other hand, market liberals can and should adopt the Group Fragmentation Thesis.

On the first question of the proper point of focus, classical theorists of standpoint epistemology argue for focusing on the group as being the epistemic focal point from which the situatedness of individuals emerges (cf. e.g. Wylie 2003). However, it should be noted that the group level cannot be the sole epistemic basis of perspectival differences. As Tanesini points out, "if the notion of standpoint is to have any plausibility, it cannot imply that without exception all those who share a social location must share a perspective" (Tanesini 2019: 2). She argues further, since one's standpoint relies on the evidence, skills, and experience of individuals, standpoint theory should take the perspective of individuals as epistemically fundamental and the group perspective only as derivative. This implies an Individualistic Fragmentation Thesis.

Individualistic Fragmentation Thesis: Perspectival differences that rest on unique characteristics of individuals generate significant amounts of knowledge for an individual that can in principle not be shared between individuals.

The counter thesis to the individualistic perspective on perspectival differences is especially prominent in advocates of community models of knowledge (Nelson 1990; Harding 1993; Potter 1993; Longino 2002). Here, the knowledge of individuals can in principle not be isolated from the community perspective. Furthermore, also consider Collins (2019) or Medina (2012) who argue for an epistemology of resistance. They suggest that for people from oppressed groups, the engagement with the group becomes fundamental in order to share experience about oppression and to organize resistance. This implies that one cannot separate the fragmentation thesis from the group perspective, as the group is so fundamental to resist epistemic oppression.

Importantly, if one defends an individualistic aspect in standpoint theory and wants to account for the significance of individualistic bottom-up perspectival differences for knowledge, one need not depart as radically from classical standpoint theory as Tanesini (2019) does. Even if one takes the individual level as the epistemic basis, it still turns out that, in practice, situated experiences (and with them knowledge) are far from being evenly distributed across groups. Thus, individuals can still be grouped according to their proclivity of forming specific clusters of knowledge and those groups can be analyzed from a feminist social epistemology perspective. In other words, even if 
the individual perspectives ground the epistemic analyses, group-based analyses remain fully compatible with them.

However, fully giving up the top-down influence of a group identity on the epistemic standpoint of individuals would amount to giving up standpoint epistemology altogether. Doing that is also not independently plausible. For instance, as one's gender furnishes perspectival differences amongst individuals, one's gender also gives one access to specific kinds of knowledge inaccessible to individuals of a different gender. For example, the experience of giving birth is inaccessible to men generally. Thus, group characteristics significantly influence what knowledge individuals can achieve. Consequently, if one finds the Individualistic Fragmentation Thesis plausible, then one may wish to combine it with the Group Fragmentation Thesis in order to account for the uniqueness of the belief-forming processes that rely both on unique individual and unique group characteristics.

Incorporating essentially individualistic and essentially group-related perspectival differences, the social situatedness of knowledge is on such an account fundamentally based on an interplay between both levels of analysis, and the epistemic basis can perhaps best be described as fluctuating between them. Since this interpretation leaves room for a research program of the knowledge generating belief-forming processes in society both at an individualistic and a group level, we leave it open for further research and debate to what degree each factor plays a role. The important takeaway of these considerations is that significant amounts of knowledge are fragmented in society across groups and individuals, and are inaccessible to certain other individuals because they do not share essential relevant characteristics.

Hayek shares his focus on the individual with Tanesini, viewing the unique access to knowledge on the group level merely as emergent from the differences in knowledge acquisition of individuals. They both endorse the Individualist Fragmentation Thesis, which shows a very specific shared epistemological commitment between Hayek's market liberalism and a subset of standpoint theories. On the other hand, one might think that market liberalism with its focus on individualism cannot endorse that subset of standpoint theories which put the Group Fragmentation Thesis at the center. This might especially suggest itself if one combines it with a community model of knowledge, where knowledge of a group is irreducible to the knowledge of individuals.

We now want to argue, however, that market liberal epistemology would actually benefit from adopting the Group Fragmentation Thesis, if properly put into context, all the while being compatible with their previous, deeply held epistemological commitments. This would widen the scope of epistemological compatibility between standpoint theory and market liberalism even further. First, consider fragmentation of knowledge in general. With the concept of perspectival differences, standpoint theory proposes a necessary fragmentation of knowledge in society, claiming that some knowledge cannot be shared across groups in principle. As shown in Hayek's example of the tin mine, we argued that for market liberalism some knowledge is such that it is factually fragmented in society but could be sharable in principle. ${ }^{22}$ Not everyone can in fact access the information of the collapse of the tin mine at the same time, and everyone's specific position at that time will impact their further understanding and reaction to that event. Nonetheless, in principle, this knowledge is sharable. Recall the initial example of the craftsman and imagine them writing a letter to a guild in Edinburgh in order to share what they have learned. Such dispersion of knowledge merely arises out of

\footnotetext{
${ }^{22}$ Note though that the knowledge conveyed by the price system is typically minimal knowledge, which is by itself sufficient for social coordination, but not necessarily for further, greater goals. We thank Nathanaël Colin-Jaeger for pressing this point.
} 
particular circumstances of time and place. However, we further argued that with Hayek's views on tacit knowledge, market liberals also endorse that significant amounts of knowledge cannot be shared in principle, as in the example of innovation. Thus, at least an individualistic take on perspectival differences is shared by market liberals.

The difference is merely that market liberals usually do not have an eye on the perspectival differences based on group characteristics as standpoint theorists do. However, this can easily be adopted by the market liberal. In fact, the Group Fragmentation Thesis will give market liberals an additional crucial explanation of why some knowledge is fragmented in society. As such, it will strengthen the claims of market liberalism because it introduces an additional mechanism for an epistemic barrier of sharing knowledge across society, directly adapted from standpoint theorists. Consequently, we argue that market liberalism would benefit from incorporating the Group Fragmentation Thesis. The unique characteristics of group identities create a necessary fragmentation of knowledge in society and the price mechanism guarantees an efficient allocation of the resources under these epistemic circumstances. Additionally, for those standpoint epistemologists who want to advocate for a community model of knowledge, this will be a factual point of contention with market liberals and their focus on methodological individualism. Note, however, that market liberals are not bound to deny a community model of knowledge either. Even if the knowledge of individuals cannot be isolated from the knowledge of the groups they belong to, the main assumption of the market liberal still holds: Only a competitive market with its price system is able to allocate resources efficiently since knowledge is dispersed - in this case - across groups. This suggests widespread theoretical compatibility.

We now move to the second apparent incompatibility. Given the thesis of market coordination based on the price system, it might appear as if the market liberal has to deny the concept of perspectival differences yet again since it seems as if the price system makes sharing of fragmented knowledge in fact possible. Standpoint epistemology, however, proposes that knowledge based on perspectival differences cannot be shared across groups. Nevertheless, notice that the market liberals only explicitly stress that the price mechanism is able to coordinate the individual actors and groups in a market even though knowledge is dispersed. They do not claim that the price system makes such knowledge directly sharable (cf. Friedman 2013). After all, market liberals stress that for a vast amount of goods, no single actor in the economy knows, for example, how the production from raw materials to the end product even works, much less how much of which product is demanded where, when, and for how long. Hayek makes this explicit by claiming that "the people guided by [the market] usually do not know why they are made to do what they do" (Hayek 1945: 527). The price system does then not straightforwardly overcome the epistemic barriers. Rather, it mediates it just as it does in more standard cases of knowledge fragmentation. That is, market liberalism merely proposes a coordination mechanism for agents in a society with fragmented knowledge in order to achieve an efficient allocation of resources. Since it does not propose that the price system makes the sharing of fragmented knowledge possible, we argue that it does not deny the thesis of perspectival differences.

A final area of difference which we want to address is the scope of fragmented knowledge. Market liberals claim that every individual has some epistemic advantage over others, whereas standpoint theorists especially focus on the epistemic advantage of oppressed groups over dominant groups, culminating in the thesis of Bifurcated Consciousness. However, we claim that both claims can complement each other. The thesis of Bifurcated Consciousness would only collide with market liberal epistemology if it were viewed as the only mechanism for a fragmentation of knowledge in society. Then, not every individual or every group would have some epistemic advantage, but 
only oppressed ones would. It is true that standpoint theorists frequently argue (e.g. Medina 2012; Collins 2019) that one type of epistemic advantage due to perspectival differences is only possible for the oppressed groups since they had to learn how to fit within the dominant epistemological system, whereas the privileged group does not have to go through such an adoption process and therefore does not gain such types of epistemic advantages.

However, there exist further mechanisms for a fragmentation of knowledge and its unsharability. Standpoint theory focuses on the epistemic advantages of oppressed groups, especially when it comes to knowledge about their oppression and about oppressive power structures and relations in society above and beyond what is publicly known. ${ }^{23}$ Market liberalism, on the other hand, often focuses on how tacit knowledge is utilized in the market mechanism. Both focus on different areas where fragmented knowledge arises in society, but the two perspectives do not stand in contradiction. Instead, they supplement each other. The thesis of Bifurcated Consciousness will enrich market liberal theories. It will add one further explanation about why knowledge is dispersed in society. Conversely, standpoint epistemology is well equipped to broaden its application, by adopting the view that all individuals and groups can have various kinds of epistemic advantages emerging from their specific position, while maintaining that some type of epistemic advantages can only be had by oppressed groups due to their experienced struggle.

In sum, we have argued that market liberalism synergizes naturally with the thesis of Perspectival Differences of standpoint epistemology. Beside the structural epistemological commonalities of these two positions, (i) dispersed knowledge, (ii) influence of position, and (iii) unsharability of knowledge, we have identified several apparent further theoretical conflicts that can be reconciled. First, market liberal epistemology already endorses the Individualist Fragmentation Thesis and, moreover, would benefit from adopting the Group Fragmentation Thesis and the thesis of the epistemic advantage of oppressed groups as well. Furthermore, market liberalism does not stand in opposition to the community model of knowledge. Second, the price mechanism in a competitive market does not amount to a denial of perspectival differences. Third, both theories focus on different epistemic advantages which should be viewed as complementary, given that they emerge from their common epistemological core assumptions. As such, the areas of fundamental disagreement were identified to be relatively small, which is rather unexpected.

\section{What to make of this?}

The finding that the epistemological assumptions of two lines of thought are that similar even though they are typically viewed as being politically opposed might be at least somewhat surprising. However, one might also expect some sound epistemological reasoning to underlie multiple positions, even politically opposed ones. What makes this case especially important is that both market liberalism and standpoint theory draw significant normative claims directly from their epistemological assumptions. As Whyte points out in the case of market liberalism, the epistemological claims are "indissociable from political claims about the good society" (Whyte 2019: 20), in this case understood to be a "capitalist society" (Whyte 2019: 20). Something similar can be said for standpoint theories and feminism. An example of this is how the epistemological core assumptions are used in the discourse on topics such as racism or sexism to argue

\footnotetext{
${ }^{23}$ Recently, it has been shown that when groups rely more heavily on public information and less on their perspectival private views, group forecasts suffer in quantity estimation tasks (Da and Huang 2020).
} 
how much weight which voices ought to have. As such, the epistemological claims have a direct pathway to political positions, making the observed epistemological similarities especially striking. In this section, we explore what these similarities mean for the projects of feminist standpoint theory, market liberal epistemology, and their respective political implications. In broad terms, we suggest that (i) market liberals ought to be more attentive to theoretical findings based on standpoint theoretic methodology in areas such as gender and racial oppression, as these claims are, at least in part, justified by epistemological commitments that the market liberals themselves endorse. Conversely, (ii) we argue that feminist scholars ought to be more open to market liberal arguments based on one's position in society on similar grounds.

As established before, the relationship between feminist thought and capitalist thought is frequently contentious in both theory and politics. However, we claim that market liberals ought to be more open to accepting and incorporating feminist thinking into their theorizing based on sharing a vast body of epistemological bedrock. More specifically, relying on the epistemic claims that knowledge is decentralized in society only when arguing for the efficient allocation of resources in the market system is unjustified if, at the same time, conclusions arrived via a markedly similar mechanism are discounted. As such, we claim, market liberals, to stay consistent with their theoretical commitments, should be more open to feminist findings in areas such as how one would come to know the disproportionate effects of capitalist systems on women and oppressed minorities. This would also help address a certain level of blindness that various market liberals have expressed when it comes to these types of feminist concerns.

Vice versa, we argue that feminists should consider arguments of market liberals more carefully as well. For the same reason as expounded above, the epistemological similarities grounding the arguments ought to give feminists reason for a deeper engagement with some aspects of market liberal thought. For instance, it might be worth to consider anti-discriminatory market-mechanisms and how an interference with them might lead to more, instead of less, discrimination (cf. Sowell 2015: 20915). More specifically, given the thesis of Bifurcated Consciousness, it could be worthwhile to explore whether the epistemic advantages of an oppressed group could be turned into an advantage for that group in a more laissez-faire market. After all, standpoint theorists argue for a significant knowledge advantage of oppressed groups and market liberals argue that many knowledge advantages, ceteris paribus, pay off in the market. If this were the case, it would suggest that the cause of some structural oppression of marginalized groups is at least partly caused by an impediment of a laissez-faire handling of the economy rather than aided by it. However, notice as well that such an appreciation will have to take place within the boundaries that further feminist commitments set.

To see this proposal in action, consider the following example of innovation. Innovation is a topic discussed by market liberals in the context of the value of competitive and free markets (cf. Pohl 2017). For Hayek, the ability to come up with novel technologies and applications is fostered by a free market that allows nondistorted communication about "what kinds of goods and services are demanded, and how urgently" (Hayek 2002: 13). On the market liberal's view, in conditions of dispersed knowledge, innovation is only properly possible if the fitting institutional arrangements, i.e. decentralized ones, are in place. For the entrepreneur in a free-market system who seeks to produce a new tool for, say, land fertilization, is best positioned to draw on their own knowledge of time and place in the context of prices. Unconstrained by a regulator, this entrepreneur is better able to innovate, fail, and try again until they produce a novel piece of technology that has the potential to be as much a boon to everybody's well-being as the fridge, modern medicine, or automated factories were. 
For the market liberal, as such, there should be minimal regulation to foster maximal innovation.

While feminists, in contrast, do not use the term "innovation" to describe much of their political work, one may reasonably understand feminists to be engaged in linguistic and conceptual innovation. Here, especially the introduction of new pronouns comes to mind. ${ }^{24}$ For instance, for those who identify as gender non-binary, the traditional set of pronouns seems to be insufficient. The degree and kind of insufficiencies and their respective challenges are in turn best understood by those who identify as gender non-binary and experience a society with a binary pronoun landscape themselves. Importantly, this innovation would also be inhibited if conceptual innovation was regulated by others who do not have the same knowledge. In other words, successful feminist innovations are driven by the knowledge that theorists and lay people have in virtue of their position in society. ${ }^{25}$ These linguistic innovations can then be put into action to, for example, address injustices, whereas heavy-handed control would impede these developments.

What we want to point out is that this line of reasoning is structurally very similar to market liberal reasoning and their way of understanding innovation in the commercial sector. Both, standpoint theorists and market liberals, understand that the ultimate driver for successful innovation is dispersed knowledge held by individuals by virtue of who they are. As such, successful innovation, be it commercial or conceptual/linguistic, cannot simply be brought into existence by a top-down decree, if it involves fragmented knowledge. Rather, it has to be driven by those who, for example, experience a certain type of oppression or experience certain shortcomings of current market solutions themselves. On this point both market liberals and standpoint theorists reason analogously and, absent any normative pre-commitments, ought to be open to the other's reasoning and conclusions on the basis of it being arrived at by such a similar mechanism.

Consider now a second example in which we present a case where the shared epistemology of standpoint theorists and market liberals suggests political synergies. This example concerns both (i) the case of shared normative commitments as well as (ii) the case of diverging normative commitments.

Let us start with (i). For such cases, the structural similarities of market liberal epistemology and standpoint epistemology are especially noteworthy because it suggests employing similar means for their common goals. Consider the goal of addressing poverty and income inequality, focusing on poverty first. This is a prime example of a societal issue dear to feminist theorizing, especially when it comes to oppressed groups who suffer disproportionately from it. It is also a normative commitment they share with various market liberals. ${ }^{26}$ In fact, Hayek (1944) himself advocates for a governmentbased social safety-net in order to address, amongst other things, poverty. We can thus identify a normative commitment that feminist standpoint theorists share with various market liberals. What policy proposals would then emerge from their shared epistemological foundation? Given the argument that individuals and groups that are themselves affected by poverty and income inequality have unique knowledge and a unique standpoint and are thus better equipped in finding policy solutions compared with a distant centralized authority, decentralized solutions should be prima facie

\footnotetext{
${ }^{24}$ Another example would be the conceptual framework of epistemic injustice (Fricker 2007).

${ }^{25}$ Feminist insights have also directly contributed to academic innovations by providing new conceptual schema through which analysis can be enriched, for example in the disciplines of philosophy (Mackenzie 2019) or political science (Weldon 2019).

${ }^{26}$ For a rights-based version, see for instance, Tomasi (2012) who views economic liberties as fundamental, while still allowing for some restrictions of these liberties based on social justice. For a synergetic view of economic freedom and equality, see Otsuka (2003).
} 
preferred to versions of a centrally planned social safety net. ${ }^{27}$ The idea is, as Tebble argues, that "the state should on epistemological grounds devolve the discovery and implementation of appropriate responses to poverty and economic inequality to individuals and voluntary associations of them" (Tebble 2009: 601).

Here, market liberals and standpoint theorists have an epistemological motivation to realize the benefits of a certain form of decentralization for poverty reduction. Particularly, they can work out policy solutions that pertain directly to the Fragmentation Thesis by capitalizing on the epistemic advantages that people affected by economic inequality and poverty have over bureaucratic state entities. Bringing market liberals and standpoint theorists together and building on these epistemic advantages promises policies that are both market-friendly while particularly keeping the needs of oppressed and marginalized groups in focus. ${ }^{28}$

Now let us move to the second version of this case (ii) in which some normative pre-commitments diverge. Take the example of addressing poverty and income inequality again, focusing primarily on income inequality. Frequently, libertarians (cf. Nozick 1974) equate state-planned redistribution with forced labor as a consequence of their concept of full self-ownership. ${ }^{29}$ As such, their normative commitment to full selfownership overrules any possibility of state-planned redistribution. They might not even view the reduction of income inequality as an issue at all, as long as it is merely a consequence of individuals exchanging rightfully acquired goods freely. Consequently, they will not agree with market liberals, such as Hayek, or various standpoint theorists on any government-based wealth redistribution program, since for them, this is an ethical non-starter.

Now interestingly, as shown in the firsts case, the shared epistemological core of market liberals and feminist standpoint theorists should motivate them to capitalize on epistemic advantages leading to bottom-up solutions. This in turn, at least for some of such proposals, will fall in line even with full self-ownership libertarians. That being said, the case also demonstrates that normative commitments might sometimes make their views diverge. Even an epistemologically informed bottom-up process might still necessitate some level of state intervention to fully address the challenges of poverty. A market liberal, such as Hayek, and most standpoint theorists would agree with such a solution, whereas libertarians in Nozick's spirit would not, and the reason is only the difference of normative commitments: How much weight is put on the value of poverty reduction and how much on the value of full self-ownership. Still, the shared epistemology promises a shared basis, and thus a more fruitful discussions on which trade-offs between various normative commitments, such as a commitment to various kinds of equality, social justice, or self-ownership, can be discussed. The examples discussed above show both the merits of bringing standpoint theory and market liberalism

\footnotetext{
${ }^{27}$ It is striking that Hayek's proposal of a centralized social safety net is at odds with his argument of dispersed knowledge. As Tebble (2009) recognizes, a decentralized solution would have been more consistent with his views.

${ }^{28}$ The literature on the relationship between decentralization and poverty reduction has been generally mixed (Von Braun and Grote 2002; Faguet and Pöschl 2015; Casey 2018), finding strong heterogeneity in effect sizes and effect directions that might be due to factors such as pre-existing government functionality (Jütting et al. 2004), institutional history (Schragger 2010), and others (Connerley et al. 2010). For further specific country-level data on the Philippines (Bird and Rodriguez 1999; Canare and Francisco 2019), Uganda (Francis and James 2003; Green 2015), India (Kalirajan and Otsuka 2012), Ghana (Crawford 2008; Agyemang-Duah et al. 2018), China (Wei 2001; Thun 2004; Wu et al. 2020), Malawi (Chinsinga 2008), Turkey (Tosun and Yilmaz 2010), Burkina Faso (Donnelly-Roark et al. 2001), Vietnam (Rao et al. 1998), or Indonesia (Nursini 2019; Talitha et al. 2020) see the above.

${ }^{29}$ As a contraposition, see Otsuka's (2003) left-libertarianism.
} 
together while also pointing out possible divergences on the basis of normative precommitments that supersede analogous reasoning on the basis of similar epistemological assumptions.

However, as we have seen at the examples discussed above, both points of view can potentially benefit theoretically and practically by considering some parts of the other's view more seriously. Both sides already draw significant normative consequences from their epistemological commitments. Thus, because of their common epistemological bedrock, they have reason to engage with the other's findings more charitably, however politically opposed they may be.

\section{Conclusion}

In this paper, we have outlined how market liberalism and feminist standpoint theories surprisingly share deep epistemological features pertaining to the individual's position in society with relation to knowledge acquisition and transmission. Furthermore, we argued that apparent theoretical incompatibilities are to a large extent reconcilable, and thus it is possible to find common ground between standpoint theorists and market liberals, even though they are often politically opposed to each other. Given that both sides draw significant normative claims from their respective epistemological foundations, we have suggested further that despite their political opposition, market liberals and standpoint theorists ought to engage deeper with the respective other's views and potentially build on their common ground. Moreover, we have claimed that proponents of either side would benefit by incorporating various insights of the other for their school of thought, especially when it comes to different contexts that their original theory does not typically cover. At least, if they view each other as politically opposed, they have to justify why such a similar epistemological bedrock that connects closely to their overarching theory could directly imply their own respective normative commitments but not the commitments of the other. ${ }^{30}$

\section{References}

Aghion P., Bloom N., Blundell R., Griffith R. and Howitt P. (2005). 'Competition and Innovation: An Inverted-U Relationship.' Quarterly Journal of Economics 120(2), 701-28.

Agyemang-Duah W., Kafui Gbedoho E., Peprah P., Arthur F., Kweku Sobeng A., Okyere J. and Mengba Dokbila J. (2018). 'Reducing Poverty through Fiscal Decentralization in Ghana and Beyond: A Review.' Cogent Economics and Finance 6(1), 1476035.

Al-Ali N. (2020). 'Covid-19 and Feminism in the Global South: Challenges, Initiatives and Dilemmas.' European Journal of Women's Studies, 1350506820943617.

Ashton N. (2020). 'Relativising Epistemic Advantage.' In M. Kush (ed.), The Routledge Handbook of Philosophy of Relativism, pp. 329-38. London: Routledge.

Aulenbacher B., Décieux F. and Riegraf B. (2018). 'The Economic Shift and Beyond: Care as a Contested Terrain in Contemporary Capitalism.' Current Sociology 66(4), 517-30.

Baehr A.R. (2021). 'Liberal Feminism.' In E.N. Zalta (ed.), The Stanford Encyclopedia of Philosophy. https:// plato.stanford.edu/archives/spr2021/entries/feminism-liberal/.

Bargu B. and Bottici C. (eds) (2017). 'Feminism, Capitalism and Critique.' In Feminism, Capitalism, and Critique: Essays in Honor of Nancy Fraser. Cham: Palgrave Macmillan.

Bento P. (2014). 'Competition as a Discovery Procedure: Schumpeter Meets Hayek in a Model of Innovation.' American Economic Journal: Macroeconomics 6(3), 124-52.

Bird R. and Rodriguez E.R. (1999). Decentralization and Poverty Alleviation: International Experience and the Case of the Philippines. Public Administration and Development: The International Journal of Management Research and Practice 19(3), 299-319.

\footnotetext{
${ }^{30}$ We thank for helpful feedback and constructive criticism Ravi Thakral, Lara Jost, Theron Pummer, Nathanaël Colin-Jaeger, Johannes Wagner, and Philipp Berghofer.
} 
Butos W.N. (2003). Knowledge Questions: Hayek, Keynes and Beyond. The Review of Austrian Economics 16(4), 291-307.

Caldwell B. (2008). Hayek's Challenge: An Intellectual Biography of FA Hayek. Chicago, IL: University of Chicago Press.

Canare T. and Francisco J.P. (2019). 'Decentralization, Fiscal Independence, and Poverty in the Philippines.' Public Budgeting and Finance 39(4), 94-117.

Casey K. (2018). 'Radical Decentralization: Does Community-Driven Development Work?' Annual Review of Economics 10, 139-63.

Cerovac I. (2018). 'Epistemic Liberalism.' Prolegomena: Casopisza Filozofiju 17(1), 81-95.

Chinsinga B. (2008). 'Decentralisation and Poverty Reduction in Malawi - A Critical Appraisal.' In G. Crawford and C. Hartmann (eds), Decentralisation in Africa, pp. 73-106. Amsterdam: Amsterdam University Press.

Code L. 1981. 'Is the Sex of the Knower Epistemologically Significant?' Metaphilosophy 12, 267-76.

Colin-Jaeger N. (Forthcoming). 'Reconstructing Liberalism: Hayek, Lippmann and the Making of Neoliberalism.' Oeconomia.

Colin-Jaeger N. and Delcey T. (2020). 'When Efficient Market Hypothesis Meets Hayek on Information: Beyond a Methodological Reading.' Journal of Economic Methodology 27(2), 97-116.

Collins P.H. (1990). Black Feminist Thought: Knowledge, Consciousness, and the Politics of Empowerment. New York, NY: Routledge.

Collins P.H. (2019). Intersectionality as Critical Social Theory. Durham, NC: Duke University Press.

Connerley E., Eaton K. and Smoke P.J. (eds) (2010). Making Decentralization Work: Democracy, Development, and Security. Boulder, CO: Lynne Rienner.

Crasnow C. (2013). 'Feminist Philosophy of Science: Values and Objectivity.' Philosophy Compass 8(4), 413-23.

Crawford G. (2008). 'Decentralization and the Limits to Poverty Reduction: Findings from Ghana.' Oxford Development Studies 36(2), 235-58.

Da Z. and Huang X. (2020). 'Harnessing the Wisdom of Crowds.' Management Science 66(5), $1847-67$.

D’Agostino F. (1996). Free Public Reason. Making It Up As We Go. Oxford: Oxford University Press.

Donnelly-Roark P., Ouedraogo K. and Ye X. (2001). Can Local Institutions Reduce Poverty? Rural Decentralization in Burkina Faso (Vol. 2677). Washington, DC: World Bank.

Dutz M.A. and Hayri A. (1999). Does More Intense Competition Lead to Higher Growth? Washington, DC: World Bank.

Eisenstein Z.R. (1979). Capitalist Patriarchy and the Case for Socialist Feminism. New York, NY: Monthly Review Press.

Epstein R.A. (1995). Forbidden Grounds: The Case Against Employment Discrimination Laws. Cambridge, MA: Harvard University Press.

Epstein R.A. (2005). 'The Uses and Limits of Local Knowledge: A Cautionary Note on Hayek.' NYU Journal of Law \& Liberty 1, 205-8.

Evans R. and Novak R.D. (1981). The Reagan Revolution. New York, NY: E.P. Dutton.

Faguet J.P. and Pöschl C. (eds) (2015). Is Decentralization Good for Development? Perspectives from Academics and Policy Makers. Oxford: Oxford University Press.

Ferguson S. (2014). 'A Response To Meg Luxton's “Marxist Feminism and Anticapitalism”.' Studies in Political Economy 94(1), 161-8.

Fiori S. (2009). 'Hayek's Theory on Complexity and Knowledge: Dichotomies, Levels of Analysis, and Bounded Rationality.' Journal of Economic Methodology 16(3), 265-85.

Fleetwood S. (1995). Hayek's Political Economy. London: Routledge.

Francis P. and James R. (2003). 'Balancing Rural Poverty Reduction and Citizen Participation: The Contradictions of Uganda's Decentralization Program.' World Development 31(2), 325-37.

Fraser N. (2012). 'Feminism, Capitalism, and the Cunning of History: An Introduction.' https://halshs. archives-ouvertes.fr/halshs-00725055/document.

Fricker M. (2007). Epistemic Injustice: Power and the Ethics of Knowing. Oxford: Oxford University Press.

Friedman J. (2013). 'Hayek's Two Epistemologies and the Paradoxes of his Thought.' Critical Review 25(34), 277-304.

Fuchs C. (2018). 'Capitalism, Patriarchy, Slavery, and Racism in the Age of Digital Capitalism and Digital Labour.' Critical Sociology 44(4-5), 677-702.

Gaus G. (2019). The Tyranny of the Ideal: Justice in a Diverse Society. Princeton, NJ: Princeton University Press. 
Goldman A.I. 1979. 'What is Justified Belief?' In G. Pappas (ed.), Justification and Knowledge, pp. 1-25. Boston: D. Reidel.

Green E. (2015). 'Decentralization and Development in Contemporary Uganda.' Regional \& Federal Studies 25(5), 491-508.

Hamati-Ataya I. (2014). 'Transcending Objectivism, Subjectivism, and the Knowledge In-Between: The Subject in/of 'Strong Reflexivity'.' Review of International Studies 40(1), 153-75.

Haraway D. (1988). 'Situated Knowledges: The Science Question in Feminism and the Privilege of Partial Perspective.' Feminist Studies 14, 575-99.

Harding S. (1982). 'Is Gender a Variable in Conceptions of Rationality: A Survey of Issues.' Dialectica 36 (2-3), 225-42.

Harding S. (1991). Whose Science? Whose Knowledge? Ithaca, NY: Cornell University Press.

Harding S. (1992). 'Rethinking Standpoint Epistemology: What is "Strong Objectivity?"' The Centennial Review 36(3), 437-70.

Harding S. (1993). 'Rethinking Standpoint Epistemology: What is Strong Objectivity?' In L. Alcoff and E. Potter (eds), Feminist Epistemologies, pp. 49-82. New York, NY: Routledge.

Harding S. (2004). The Feminist Standpoint Theory Reader: Intellectual and Political Controversies. London: Routledge.

Hartsock N.C.M. (1983). 'The Feminist Standpoint: Developing the Ground for a Specifically Feminist Historical Materialism.' In S. Harding and M.B.P. Hintikka (eds), Discovering Reality: Feminist Perspectives on Epistemology, Metaphysics, Methodology, and Philosophy of Science, pp. 283-310. Dordrecht: Springer.

Harvey D. (2005). The New Imperialism. Oxford: Oxford University Press.

Hayek F.A. (1944). The Road to Serfdom, Chicago, IL: University of Chicago Press.

Hayek F.A. (1945). 'The Use of Knowledge in Society.' American Economic Review 35(4), 519-30.

Hayek F.A. (1952). The Sensory Order. London: Routledge \& Paul Kegan.

Hayek F.A. (ed.) (1967). 'Rules, Perception, and Intelligibility.' In Studies in Philosophy, Politics and Economics, pp. 43-65. Chicago, IL: University of Chicago Press.

Hayek F.A. (1976). The Mirage of Social Justice. Vol. 2 of Law, Legislation and Liberty. Chicago, IL: University of Chicago Press.

Hayek F.A. (1988). Fatal Conceit: The Errors of Socialism. Chicago, IL: University of Chicago Press.

Hayek F.A. (2002). 'Competition as a Discovery Procedure.' Quarterly Journal of Austrian Economics 5(3), 9-23.

Hekman S. (1997). 'Truth and Method: Feminist Standpoint Theory Revisited.' Signs: Journal of Women in Culture and Society 22(2), 341-65.

Huang Z., Li L., Ma G. and Xu L.C. (2017). 'Hayek, Local Information, and Commanding Heights: Decentralizing State-Owned Enterprises in China.' American Economic Review 107(8), 2455-78.

Intemann K. (2010). '25 Years of Feminist Empiricism and Standpoint Theory: Where are We Now?' Hypatia 25(4), 778-96.

Jaggar A. (1983). Feminist Politics and Human Nature. Totowa, NJ: Rowman and Allanheld.

Jütting J.P., Kauffmann C., McDonnell I., Osterrieder H., Pinaud N. and Wegner L. (2004). 'Decentralization and Poverty in Developing Countries: Exploring the Impact.' https://ssrn.com/ abstract $=583762$.

Kalirajan K. and Otsuka K. (2012). 'Fiscal Decentralization and Development Outcomes in India: An Exploratory Analysis.' World Development 40(8), 1511-21.

Khalil E.L. (2002). 'Information, Knowledge and the Close of Friedrich Hayek's System.' Eastern Economic Journal 28(3), 319-41.

Kiesling L. (2015). 'The Knowledge Problem.' In C.J. Coyne and P. Boettke (eds), Oxford Handbook of Austrian Economics, pp. 45-64. Oxford: Oxford University Press.

Kirp D.L., Yudof M.G. and Franks M.S. (1986). Gender Justice. Chicago, IL: University of Chicago Press.

Kukla R. (2006). 'Objectivity and Perspective in Empirical Knowledge.' Episteme 3(1-2), 80-95.

Lara M.P. (2017). 'Feminism, Ecology, and Capitalism: Nancy Fraser's Contribution to a Radical Notion of Critique as Disclosure.' In B. Bargu and C. Bottici (eds), Feminism, Capitalism, and Critique: Essays in Honor of Nancy Fraser, pp. 119-37. Cham: Palgrave Macmillan.

Lister A. (2013). 'The "Mirage” of Social Justice: Hayek Against (and for) Rawls.' Critical Review 25(3-4), $409-44$.

Longino H. (2002). The Fate of Knowledge, Princeton, NJ: Princeton University Press.

Luxton M. (2014). 'Marxist Feminism and Anticapitalism: Reclaiming our History, Reanimating our Politics.' Studies in Political Economy 94(1), 137-60. 
Lyberaki A. (2011). 'Migrant Women, Care Work, and Women's Employment in Greece.' Feminist Economics 17(3), 103-31.

Mackenzie C. (2019). 'Feminist Innovation in Philosophy: Relational Autonomy and Social Justice.' Women's Studies International Forum 72, 144-51.

Medina J. (2012). The Epistemology of Resistance: Gender and Racial Opression, Epistemic Injustice, and Resistant Imaginations. Oxford: Oxford University Press.

Michaelian K. (2008). 'Privileged Standpoints/Reliable Processes.' Hypatia 23(1), 65-98.

Mills C.W. (2007). 'White Ignorance.' In S. Sullivan and N. Tuana (eds), Race and Epistemologies of Ignorance. Albany, NY: State University of New York Press.

Mojab S. (ed.) (2015). Marxism and Feminism. London: Zed Books.

Moore J.W. (2015). Capitalism in the Web of Life: Ecology and the Accumulation of Capital. London: Verso Books.

Muldoon R. (2016). Social Contract Theory for a Diverse World: Beyond Tolerance. London: Taylor \& Francis.

Naples N.A. (2009). 'Teaching Intersectionality Intersectionally.' International Feminist Journal of Politics 11, 566-77.

Naples N.A. and Gurr B. (2013). 'Feminist Empiricism and Standpoint Theory. Approaches to Understanding the Social World.' In S.N. Hesse-Biber (ed.), Feminist Research Practice: A Primer, pp. 14-41. London: Sage.

Nelson L.H. (1990). Who Knows: From Quine to a Feminist Empiricism. Philadelphia, PA: Temple University Press.

Nozick R. (1974). Anarchy, State and Utopia, New York, NY: Basic Books.

Nursini N. (2019). 'Poverty Alleviation in the Context of Fiscal Decentralization in Indonesia.' Economics \& Sociology 12(1), 270-368.

O’Brien M. (1981). The Politics of Reproduction. New York, NY: Routledge \& Kegan Paul.

O'Driscoll Jr. G.P. (2016). 'Monetary Policy and the Knowledge Problem.' Cato Journal 36(2), 337-52.

Oğuz F. (2010). 'Hayek on Tacit Knowledge.' Journal of Institutional Economics 6(2), 145-65.

Oksala J. (2017). 'Feminism, Capitalism, and the Social Regulation of Sexuality.' In B. Bargu and C. Bottici (eds), Feminism, Capitalism, and Critique: Essays in Honor of Nancy Fraser, pp. 67-83. Cham: Palgrave Macmillan.

O’Neill J. (2006). 'Knowledge, Planning, and Markets: A Missing Chapter in the Socialist Calculation Debates.' Economics \& Philosophy 22(1), 55-78.

Otsuka M. (2003). Libertarianism without Inequality. Oxford: Clarendon Press.

Page L. and Siemroth C. (2020). 'How Much Information is Incorporated in Financial Asset Prices? Experimental Evidence.' Review of Financial Studies. https://doi.org/10.1093/rfs/hhaa143.

Petsoulas C. (2013). Hayek's Liberalism and its Origins: His Idea of Spontaneous Order and the Scottish Enlightenment. London: Routledge.

Pohl T.A. (2017). Four Evangelists for Leading Innovation - von Hayek, Schumpeter, Coase, von Thünen (No. 2017-43). Wittener Diskussionspapiere zu alten und neuen Fragen der Wirtschaftswissenschaft.

Polanyi K. (1944). The Great Transformation. New York, NY: Farrar \& Rinehart.

Potter E. (1993). 'Gender and Epistemic Negotiation.' In L. Alcoff and E. Potter (eds), Feminist Epistemologies, pp. 161-86. New York, NY: Routledge.

Potts J. (2016). 'What is the Innovation Problem?' Available at SSRN 2842080.

Radnitzky G. (1992). 'Hayek's Contribution to Epistemology, Ethics and Politics.' Journal des Economistes et des Etudes Humaines 3(2-3), 219-36.

Ranelagh J. (1991). Thatcher's People: An Insider's Account of the Politics, the Power and the Personalities. London: HarperCollins.

Rao M.G., Bird R.M. and Litvack J.I. (1998). 'Fiscal Decentralization and Poverty Alleviation in a Transitional Economy: The Case of Viet Nam.' Asian Economic Journal 12(4), 353-78.

Rolin K. (2006). 'The Bias Paradox in Feminist Standpoint Epistemology.' Episteme 3(1-2), 125-36.

Rolin K. (2009). 'Standpoint Theory as a Methodology for the Study of Power Relations.' Hypatia 24(4), 218-26.

Rose H. (1983). 'Hand, Brain, and Heart: A Feminist Epistemology for the Natural Sciences.' Signs 9(1), 73-90.

Schragger R.C. (2010). 'Decentralization and Development.' Virginia Law Review 96(8), 1837-1910.

Schultz A. and Libman A. (2015). 'Is there a Local Knowledge Advantage in Federations? Evidence from a Natural Experiment.' Public Choice 162(1-2), 25-42. 
Sowell T. (2015). Basic Economics. A Common Sense Guide to the Economy, 5th edition. New York, NY: Basic Books.

Smith D.E. (1974). 'Women's Perspective as a Radical Critique of Sociology.' Sociological Inquiry 4(1), 1-13.

Talitha T., Firman T. and Hudalah D. (2020). 'Welcoming Two Decades of Decentralization in Indonesia: A Regional Development Perspective.' Territory, Politics, Governance 8(5), 690-708.

Tanesini A. (2019). 'Standpoint Theory Then and Now.' In The Routledge Handbook of Social Epistemology. London: Routledge.

Tebble A. J. (2009). 'Hayek and Social Justice: A Critique.' Critical Review of International Social and Political Philosophy 12(4), 581-604.

Thicke M. (2018). 'Market Epistemology.' Synthese 195(12), 5571-94.

Thun E. (2004). 'Keeping up with the Jones': Decentralization, Policy Imitation, and Industrial Development in China.' World Development 32(8), 1289-308.

Tingvall P.G. and Poldahl A. (2006). 'Is There Really an Inverted U-Shaped Relation Between Competition and R\&D?' Economics of Innovation and New Technology 15(2), 101-18.

Toole B. (2019). 'From Standpoint Epistemology to Epistemic Oppression.' Hypatia 34(4), 598-618.

Tomasi J. (2012). Free Market Fairness. Princeton, NJ: Princeton University Press.

Tosun M.S. and Yilmaz S. (2010). 'Decentralization, Economic Development, and Growth in Turkish Provinces.' Emerging Markets Finance and Trade 46(4), 71-91.

Tuana N. (2004). 'Coming to Understand: Orgasm and the Epistemology of Ignorance.' Hypatia 19(1), 194-232.

Tuana N. (2006). 'The Speculum of Ignorance: The Women's Health Movement and Epistemologies of Ignorance.' Hypatia 21(3), 1-19.

Vaughn K. (1994). Austrian Economics in America. New York, NY: Cambridge University Press.

Von Braun J. and Grote U. (2002). 'Does Decentralization Serve the Poor?' In E. Ahmad and V. Tanzi (eds), Managing Fiscal Decentralization, pp. 92-119. London: Routledge.

Von Mises L. (1920). 'Die Wirtschaftsrechnung im sozialistischen Gemeinwesen.' Archiv für Sozialwissenschaften 47.

Von Mises L. (1951). Socialism: An Economic and Sociological Analysis. New Haven, CT: Yale University Press.

Walby S. (1989). 'Theorising Patriarchy.' Sociology 23(2), 213-34.

Walby S. (2013). Patriarchy at Work: Patriarchal and Capitalist Relations in Employment, 1800-1984. Chichester: Wiley.

Wei Y.D. (2001). 'Decentralization, Marketization, and Globalization: The Triple Processes underlying Regional Development in China.' Asian Geographer 20(1-2), 7-23.

Weldon S.L. (2019). 'Power, Exclusion and Empowerment: Feminist Innovation in Political Science.' Women's Studies International Forum 72, 127-36.

Whyte J. (2019). 'The Invisible Hand of Friedrich Hayek: Submission and Spontaneous Order.' Political Theory 47(2), 156-84.

Wu H., Li Y., Hao Y., Ren S. and Zhang P. (2020). 'Environmental Decentralization, Local Government Competition, and Regional Green Development: Evidence from China.' Science of The Total Environment 708, 135085.

Wylie A. (2003). 'Why Standpoint Matters.' In R. Figueroa and S. Harding (eds), Science and Other Cultures: Issues in Philosophies of Science and Technology, pp. 26-48. New York, NY: Routledge.

Young I. (1980). 'Socialist Feminism and the Limits of Dual Systems Theory.' Socialist Review 10(2/3), 169-88.

Raimund Pils is a PhD student and assistant at the University of Salzburg.

Philipp Schoenegger is a PhD student at the University of St Andrews. Email: ps234@st-andrews.ac.uk.

Cite this article: Pils R, Schoenegger P (2021). On the Epistemological Similarities of Market Liberalism and Standpoint Theory. Episteme 1-21. https://doi.org/10.1017/epi.2021.13 